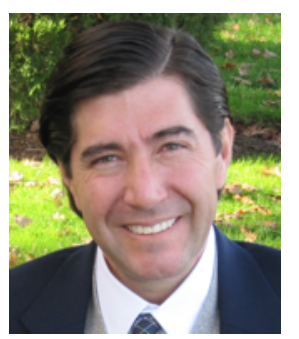

\title{
WATER LAW, MINING AND HYDRO-ENERGY CONFLICTS IN SOUTH AMERICA: TALES FROM THE ANDES AND PATAGONIA
}

\section{Victor M Tafur}

Environmental lawyer based in New York, USA (www.victortafurlaw.com) currently Visiting Professor of Environmental Law at Bard College's Center for Environmental Policy in New York, USA and Adjunct Faculty at Pace University school of Law in New York, USA.

Conflicts in connection with hydro-energy and mining activities vis-à-vis other water uses, mainly human consumption, agriculture, industry, tourism, or even the essential flows needed for ecosystem protection, call into question whether South America's path in the 21st Century will be characterized as 'open veins' (borrowing from the title of Uruguayan writer Eduardo Galeano's book) or sustainable development. In this era of 'New Conquistadors', as some have called it, the key question is whether water law and environmental legal frameworks in the region are fit to deal with the pressure posed by these extracting industries. The paper seeks to contribute to this debate by discussing legal issues in connection with a controversial gold mining project in the Argentina-Chile border and a hydro-energy project in the Chilean Patagonia. The goal of the paper is to provide a South American perspective of water law through the lens of conflict.

The paper concludes that water-related conflicts in these projects reveal weaknesses in the regulatory scheme for such endeavours and underscores the need to adopt reforms or implement mechanisms to ensure that water resources are adequately assessed, protected, and monitored.

\section{Introduction}

Conflicts in connection with hydro-energy and mining activities vis-à-vis other water uses, mainly human consumption, agriculture, industry, tourism or even the essential flows needed for ecosystem protection, call into question whether South America's path in the $21^{\text {st }}$ Century will be characterized as 'open veins' (borrowing from the title of Uruguayan writer Eduardo Galeano's book on the previous five centuries in the region) ${ }^{1}$ or sustainable development - the concept that gained worldwide recognition in the Rio Declaration in $1992 .^{2}$

In the last decade, South American mining and energy sectors regained dominance, becoming key players in the economies of the region, investing billions of dollars in their extracting industries and, at the same time, using exponential amounts of water to carry out their operations. With robust demand for energy, and both precious and base metals, energy and mining activities in the region are expanding at an alarming rate. The opening of a new wave of mines up and down the South American continent is drawing much attention and uproar from other water users. It seems clear that many mining projects that were technically or economically non-viable in the past are now worthy of investment, in particular, gold extracting operations - whether in the Andes or in river beds throughout the region - not to mention illegal activities. Similarly, hydro-energy projects are being proposed in areas of the Amazon and Patagonia that were unimaginable in the past.

Eduardo Galeano, Open Veins of Latin America, (Siglo XXI Editores, $3^{\text {rd }}$ ed, 2004).

2 United Nations Conference on Environment and Development, Rio Declaration on Environment and Development, UN Doc A/CONF.151/26 (14 June 1992). 
At the center of these conflicts is a legal juxtaposition of various sets of laws - including water, mining, energy and environmental - and their corresponding policies. South American countries have over four decades of environmental law reform, starting with natural resources codes in the 70 s that were later complemented with framework environmental laws in the 90s, and their implementation thereafter - both in the regulatory and institutional fronts. Water law reform, however, has been slow or non-existent. Energy and mining law reform have restructured the relevant sectors and encouraged privatizations, as well as incentives to attract exploration and investments. Changes have been introduced to incorporate sustainability principles in the mining and energy sectors, though these changes have not been strong. However, it has become clear recently, with the advent of large-scale projects in the mining and hydro-energy sectors, that the real-life application of such regulatory schemes needs further adjustment and proper implementation.

In this era of 'New Conquistadors', as some have called it, the key question is whether water law and environmental legal frameworks in the region are fit to deal with the pressure posed by the extracting and energy industries. The paper seeks to contribute to this debate by discussing legal issues in connection with a controversial gold mining project in the Argentina-Chile border as well as a hydro-energy project in the Chilean Patagonia, followed by brief concluding remarks. The ultimate goal of the paper is to provide a South American perspective of water law through the lens of conflict.

\section{Water and mining conflicts: The Pascua-Lama project}

Gold mining is booming all over the South American continent, even high in the Andes between Argentina and Chile. The largest of such projects is Pascua-Lama, a vast open-pit gold mining project that the Canadian company Barrick Gold is developing at an altitude of 3800-5200 meters, expected to begin production in $2013 .{ }^{3}$ Pascua-Lama's site straddles the Chilean-Argentine border, thus a bi-national mining agreement was adopted in 1997 (ratified in 2000) and supplemented with a Protocol in 1999 and 2004 specifically to promote this project. ${ }^{4}$ Another Barrick Gold mine in the Argentine side - about 10 kilometers from Pascua-Lama - is a gold and silver project called Veladero, which is already in operation. These projects have been endorsed by the national and provincial governments, due to employment opportunities and local investments, but the potential impacts on the environment, mainly water resources, remain uncertain.

Pascua-Lama's operations include drilling and blasting in the open-pit and hauling the ore by truck to a primary crushing plant, with a mining rate of approximately 300000 tons per day, mostly on the Chilean side. ${ }^{5}$ Ore will be transported to a primary crushing plant at the edge of the pit in Chile. A five-kilometer-long conveyor system will transfer the ore to covered stockpiles in Argentina, where the processing plant is to be located. The environmental impact assessment (EIA) for Pascua-Lama was approved in 2006 by environmental authorities on both sides of the Andes.

The Pascua-Lama EIA controversies centre primarily on the anticipated impacts on water resources, including on the glaciers and permafrost areas. With respect to water use, the mining operations on the Chilean side will draw water from the Huasco River. ${ }^{6}$ To that end, Barrick Gold hold water rights under the 1981 Water Code, ${ }^{7}$ but needs to comply with conditions set forth

\footnotetext{
3 Barrick Gold Corporation, Building Pascua-Lama-Factsheet (2009), 1-3, <http://www.barrick.com/Theme/Barrick/files/docs_project/PascuaLamaFactsheet-May2009.pdf>.

4 Tratado entre la República de Chile y la República Argentina sobre Integración y Complementación Minera, ArgentinaChille, signed 29 December 1997; Protocolo Complementario, Argentina-Chile, signed 20 August 1999; Protocolo Adicional Proyecto Minero Pascua Lama, Argentina-Chile, signed13 August 2004, <www.mineria.gov.ar>

Approximately $75 \%$ of the ore body is located on the Chilean side of the border; $25 \%$ in Argentina.

6 Chile's Pascua-Lama ElA Approval, (República de Chile), Comisión Nacional del Medio Ambiente, Región Atacama, Resolucion Exenta No 024 del 15 de febrero de 2006, <https: / /www.e-

seia.cl/externos/admin_seia_web/archivos/6316_2006_2_15_RE.pdf, at 106-109; 139-140; 145-146; 153-154>.

Chile's Water Code, (República de Chile) Decreto con Fuerza de Ley No 1122 de 1981, amended by Ley 20017 de 2005.
} 
under environmental approvals. ${ }^{8}$ On the Argentinian side, where the mine's processing plant is to be located and more water is required, the operation has been permitted to draw water from the Las Taguas River. Water used in the processing of ore will be captured, recycled and re-used to minimise the withdrawal of fresh water, but runoff is a potential problem, hence monitoring is essential. Water monitoring starts on the property on both sides of the border and continues 45 kilometers downstream in Chile and about 100 kilometers downstream in Argentina. ${ }^{9}$

Impacts on glacier and permafrost areas have also raised legal and social conflicts. A 2010 Argentine federal law, establishing minimum protective standards for glaciers and peri-glacial areas throughout the country - restricting or even banning mining activities in such areas - is creating a political turmoil and making its way through the courts, although it is unclear how it will apply to specific projects such as Pascua-Lama. ${ }^{10}$ In contrast, Chilean Bills aimed at conserving glacier and peri-glacial areas have failed.

In any event, impacts on these resources, on both sides, remain a great concern. These and other issues concerning the separate EIA approvals of the Pascua-Lama project are succinctly considered below.

\section{The Pascua-Lama project in Argentina}

Argentina has a federal system of government with the provinces having original ownership of their natural resources, according to the Constitution adopted in $1994 .{ }^{11}$ Accordingly, the provincial government of San Juan, where Pascua-Lama is located, is mainly responsible for the approval and monitoring of the EIA for the project under provincial laws. But, Argentine federal law is applicable as well, in particular the Federal Mining Law ${ }^{12}$ - which applies to the entire territory under a separate constitutional provision ${ }^{13}$ - amended in 1995 to require environmental protection in mining activities. ${ }^{14}$ In addition, under the Federal Environmental Framework Law, environmental minimum standards can be adopted as a minimum 'floor' throughout the country. ${ }^{15}$ This law also attempts to coordinate the roles of the federal, provincial and local governments in the implementation of the environmental laws. Notably, however, in Argentina, as in a few other countries of the region, mining and energy authorities are primarily in charge of the EIA review and follow-up in their respective sectors. ${ }^{16}$

Under this regulatory scheme, the EIA for Pascua-Lama was the responsibility of the Ministry of Mining of the Province of San Juan federal. ${ }^{17}$ An initial EIA for Pascua-Lama submitted in 2000 was withdrawn by the applicant due to deficiencies. In the meantime, the EIA for the nearby Veladero project was filed and approved in 2003. The following year, the revised EIA for PascuaLama was submitted for review and was subject to review by an ad-hoc special commission integrated with federal and state agencies. ${ }^{18}$ There were opportunities for public participation after which the EIA was approved in 2006. ${ }^{19}$

\footnotetext{
8 Chile's Pascua-Lama EIA Approval, above n 6.

9 Barrick Gold Corporation, above n 3.

${ }^{10}$ Argentina's Glacier-Protection Law, (República de Argentina) Ley No 26639 de 2010, Régimen de Presupuestos Mínimos para la Preservación de los Glaciares y del Ambiente Periglacial.

${ }^{11}$ Constitución de Argentina, Artículo 124; See Victor M Tafur, Sustainable Energy Law in Latin America, (Doctoral Dissertation, Pace University, 2006), 77-78 <http://digitalcommons.pace.edu/lawdissertations/3>.

12 Argentina's Mining Law, (República de Argentina) Decreto No 456 de 1997, (English translation <http://www.mineria.sanjuan.gov.ar/legislacion/leg_minera_arg/MINING\%20CODE.pdf.>)

${ }^{13}$ Constitución de Argentina, Artículo 75 (12).

${ }^{14}$ Federal Mining Law (República de Argentina) Provincia San Juan, Ley No 25583 de 1994, <http://www.mineria.sanjuan.gov.ar/legislacion/nacion/pdf/24585.PDF>.

${ }^{15}$ Federal Environmental Framework Law, (República de Argentina) Ley No 25675 de 2002; see also Tafur, above n 11, $101-2$.

16 Tafur, above n 11, 356-359.

${ }^{17}$ Ministry of Mining of the Province of San Juan federal, <http://www. mineria.sanjuan.gov.ar/>.

${ }^{18}$ Comisión Interdisciplinaria de Evaluación Ambiental Minera, created by provincial 'Decreto No. 1815 de 2004', <http://www.mineria.sanjuan.gov.ar/legislacion/provincia/pdf/DECRETO_1815_CREACION_CIEAM.pdf>.

19 Argentina's Pascua-Lama ElA Approval (República de Argentina) Provincia San Juan, Resolución No. 121-SEM-06 de 4 de diciembre de 2006.
} 
Subsequently, in late 2010, the Argentine Glacier-Protection Bill became law, after a similar Bill had been by vetoed by the President in 2008. This law is clearly aimed at curbing mining and oil operations on glaciers and in so-called peri-glacial area. Notably, the new legislation does not just prohibit mining and oil activity directly affecting glaciers, but also bans such work on socalled 'peri-glacial' land or permafrost, defining this as an area of 'frozen soils that acts as a water-resource regulator'. ${ }^{20}$ Furthermore, the law calls for an inventory of such resources. ${ }^{21}$

The conflicts surrounding the new Glacier-Protection Law also call into question federalism issues. The legislation cleared the Senate in a tight vote after several Argentine provincial governors appeared before Congress to argue against the legislation. On the legal front, the central issue is whether the legislation would violate the Argentine Constitution, which gives the provinces authority over their natural resources. However, the law is grounded on another constitutional provision that empowers Congress to set minimum standards for environmental protection. ${ }^{22}$

The application of the Glacier-Protection Law to the Pascua-Lama project has sparked protests and litigation. A few days after the new Argentine glacier-protection legislation became effective, an Argentine federal judge suspended implementation of the measure on grounds its prohibition on mining in glacial and peri-glacial areas might infringe on the constitutional right of provinces to control their natural resources. The injunction was made by a federal judge in the Province of San Juan, and temporarily suspends the law's implementation in the province pending a review of the legislation's constitutionality, a process expected ultimately to involve the country's Supreme Court. ${ }^{23}$ In March 2011, the Federal Government adopted a decree implementing the law's requirement (with established guidelines for such process) to produce an inventory of the glacier and peri-glacial systems. ${ }^{24}$ Later, a lawsuit was brought to specifically require the application of the of the Glacier-Protection Law to the Pascua-Lama project. ${ }^{25}$ Thus, the controversy regarding this aspect of the project persists. ${ }^{26}$

\section{The Pascua-Lama project in Chile}

On the other side of the Andes, Chile has a unitary system of government coupled with decentralization of functions, and a more rigorous structure for environmental review by the environmental agencies, though public participation is quite limited. Under this structure, the EIA for Pascua-Lama was reviewed by the Regional Commission of the Environment (COREMA) in the Acatama Region, pursuant to the 1994 General Environmental Law and it's 1997 implementing regulation. ${ }^{27}$ The EIA for the project was submitted in 2004 and was approved in 2006, subject to several conditions, mainly to do with water and glacier monitoring. ${ }^{28}$ Public participation was limited to a single opportunity to comment on the original proposal to be made within 60 days from the initial submission of the EIA. The COREMA responded to these comments in the final approval in 2006. ${ }^{29}$ Several agencies also commented and requested additional information, which resulted in three rounds of supplemental submissions.

\footnotetext{
${ }^{20}$ Argentina's Glacier-Protection Law, above n 10, arts 2 and 6.

${ }^{21}$ Ibid arts 3-5.

${ }^{22}$ Constitución de Argentina, art 41.

${ }^{23}$ See EcoAmericas: A monthly report on development and the Environment in Latin America, October 2011 and April 2011 $<$ http://www.ecoamericas.com/>.

${ }^{24}$ Argentina's Glacier-Protection Regulation, (República de Argentina) Decreto No 207 de 2011, Apruébase la Reglamentación del Régimen de Presupuestos Mínimos para la Preservación de los Glaciares y del Ambiente Periglacial.

${ }^{25}$ See discussions on Protectcción glaciares - el blog, <http://proteccionglaciares.blogspot.com/>; Greenpeace blog <http://www.greenpeace.org.ar/blog/etiqueta/glaciares/>.

${ }^{26}$ Ibid; see also Barrick: Minería responsible de destruir los glaciares, (Julio 2011) Greenpeace <http://www.greenpeace.org/argentina/Global/argentina/report/2011/cambio_climatico/barrick_mineria_responsabl e.pdf $>$.

${ }^{27}$ Chile’s General Environmental Law (República de Chile) Ley No 19300 of 1994 as amended by Ley No 20417 de 2010.

${ }^{28}$ See Chile's Pascua-Lama EIA Approval, above n 6.

${ }^{29}$ Ibid.
} 
As noted earlier, mining operations will draw water from the Huasco River. Barrick Gold holds the necessary water rights under the 1981 Chilean Water Code for its operations, ${ }^{30}$ but needs to comply with conditions set forth under environmental approvals. In response to public comments and those of involved agencies, the EIA approval imposed various conditions, mainly to do with water monitoring. In addition to required monitoring, the applicant committed to establishing a fund for independent monitoring and for the construction of a dam, as way of compromise with water users in the Huasco Valley. ${ }^{31}$

Regarding impact on icefields, glaciers, and peri-glacial areas, the Chilean EIA approval of Pascua-Lama concluded that the company shall only access the ore in a manner that does not remove, relocate, destroy or physically intervene with specifically identified glaciers in the area (specifically, the Toro 1, Toro 2 and Esperanza glaciers), rejecting the applicant's proposal to intervene in the resources. ${ }^{32}$ The environmental authority has been monitoring the project as required in the EIA approval and disclosing the relevant documents..$^{33}$ In 2010, COREMA initiated enforcement procedures regarding illegal withdrawal of water and discharges as well as potential adverse impacts on glaciers that culminated in the first administrative fine in $2011 .^{34}$

\section{Hydro-energy conflicts: The HidroAysén project in Chile}

Hydroelectric generation projects have proliferated in South America in the last few decades in response to the region's struggle to meet growing energy demand. While some of these projects are small non-controversial run-of-river projects, others are large controversial proposals spanning from the Amazon region to the Patagonia. The proposed 2750 megawatt HidroAysén project in the Chilean Patagonia is emblematic of such conflicts. A joint venture of Empresa Nacional de Electricidad SA (Endesa) and Colbun SA, the HidroAysén proposal consists of five dams: two dams in the Baker River and three additional dams in the Pascua River, that would flood an area of approximately 6000 hectares and will utilize essentially all water rights in the surrounding area. The EIA for the dams as well as additional water rights needed for the project, were approved in May $2011,{ }^{35}$ although under two separate reviews. The joint venture also needs to build a 2500 kilometer-transmission line to carry the electricity from Patagonia to the Chilean Interconnected Central System grid, which serves over 90 per cent of the population, but this component of the project has not been submitted for EIA review.

The immediate question that comes to mind is: why dam the pristine Baker and Pascua rivers in Patagonia 2500 kilometers from Santiago? The project proponent explains:

The Baker and Pascua rivers are characterized by their abundant flows and little variation, if compared to other rivers in the central zone of Chile. Both rivers receive the water from lakes Bertrand and O'Higgins, respectively; in turn, they are fed by the thaw from two big glacier masses: Campo de Hielo Norte and Campo de Hielo Sur. This special characteristic results in the Baker and Pascua rivers presenting their largest flows when the central zone rivers, due to the lack of rain and snow, present their lowest flow levels. In other words, they provide an additional resource for those that are used in the central zone of Chile. ${ }^{36}$

The project's environmental approval followed two separate tracks: first, the required EIA and permitting process for the dams before the regional environmental authority, subject to consultation with other involved agencies and with limited public participation; second, an application

\footnotetext{
${ }^{30}$ Chile's Water Code, above n 7.

${ }^{31}$ Chile's Pascua-Lama EIA Approval, above n 6, 145.

32 Ibid 129-31, 145, 163-164, 173 para 9.22.

${ }^{33}$ See Servicio de evaluación ambiental, <http: / / www.sea.gob.cl/>.

${ }^{34}$ Comisión Nacional del Medio Ambiente, República de Chile, Región Atacama, Resolución Exenta No 22 de 1 de febrero de 2011, http://seia.sea.gob.cl/archivos/RES_PASCUA_LAMA.pdf; see also, Resolución Exenta No 22 de 26 de enero de 2010, <http://seia.sea.gob.cl/externos/sanciones/archivos/SAN_idExp1048260_idSan1963.PDF>.

${ }^{35}$ Comisión Nacional del Medio Ambiente, Región Aysén, Chile’s HidroAysén ElA Approval (República de Chile, Resolución Exenta No 225 de 13 de mayo de 2011, <http://seia.sea.gob.cl/archivos/RCA_3103211.pdf>.

${ }^{36}$ HidroAysén's EIA, Executive Summary, <www. hidroaysen.cl>
} 
for additional water rights needed for the project before the Chilean Water Agency (the proponents asserted already having rights to around 60-70 per cent of the flows needed for the dams), which is an administrative process seeking the determination to grant or deny the property rights for the non-consumptive use of water resources. Although the project cleared initial approvals for both tracks, litigation has followed both approvals. As noted above, the filing of an EIA for the transmission line is still pending.

What makes the conflicts surrounding this project particularly interesting is that Chile has essentially privatized water resources and embraced market-based water policies, at the same time as a result of joining the group of OECD countries in 2010 - that it has embarked in establishing a high-quality regulatory system for environmental protection. The 1980 Constitution, passed during the Pinochet regime, establishes the basis for such a framework, having recognized the individual's 'right to live in an environment free from contamination' and 'the state's duty to guard against infringement of this right and to oversee the conservation of nature'.$^{37}$ Subsequently, the 1981 Water Code incorporated a market-based approach to water law. ${ }^{38}$ The 1982 electricity law restructured the sector; the initiative became a world's first to unbundle the electric functions monopolised by large utilities, followed by reforms in the United Kingdom, other Latin American countries and many other nations as well. In the Post-Pinochet era, the General Environmental Law was passed in 1994, which included the requirement of an EIA and permitting for major actions and projects. ${ }^{39}$ This legislation was overhauled in 2010 to partially amend the EIA process and to restructure the environmental institutional framework, as recommended during the OECD membership process. ${ }^{40}$ As the HidroAysén project illustrates, Chile is struggling to reconcile these legal frameworks.

\section{HidroAysén's environmental impact review conflicts}

In August of 2008, HidroAysén submitted the EIA to the Regional Commission of the Environment (COREMA) in the Aysén Region for its review pursuant to the 1994 General Environmental Law and its 1997 implementing regulation. ${ }^{41}$ After several requests to clarify and supplement, the project's EIA cleared approval in 2011 without any substantive changes or conditions other than those offered by the applicant; ${ }^{42}$ hence, as expected, litigation has ensued.

As with the Pascua-Lama EIA review, public participation was limited to a single opportunity to comment on the original proposal, within 60 days from the initial submission of ElA review. There were no opportunities for public comment regarding the three supplemental EIA submissions required by the COREMA and other involved agencies, despite questions regarding substantial issues on the project and its impacts. The COREMA responded to the 2008 public comments in the final approval in 2011, mainly noting that the observations were either irrelevant or had been adequately considered by the environmental authorities. ${ }^{43}$

An interesting issue in the EIA review was raised by the Forest Agency (CONAF). CONAF maintained, in the early phases of the evaluation process, that one of the obstacles for approving the project was the partial flooding of Laguna San Rafael National Park. This, CONAF contended, would violate Chilean Forestry Law and other environmental laws. In the last round of comments, however, CONAF officials in Santiago overruled the comments by the regional office, asserting that the flooding of 18 hectares of the park is not illegal and that the dams could be approved, subject to the compensation measures offered by the applicant.

\footnotetext{
${ }^{37}$ Constitución de Chile, art 19.8.

${ }^{38}$ Chile's Water Code, above $\mathrm{n} 7$.

${ }^{39}$ Chile's General Environmental Law, above n 27.

${ }^{40}$ Ibid.

${ }^{41}$ Ibid.

${ }^{42}$ Chile's HidroAysén EIA Approval, above n 35.

${ }^{43}$ Ibid.
} 
Other important issues, derived from the comments by the Water Agency - which was also reviewing the applicant's request for additional water rights under a separate track (discussed in the following section) - relate to the potential impacts of the project on water resources and glaciers. The Water Agency repeatedly complained of inadequacies in the EIA, mainly inadequate analyses or the lack of information regarding impacts on water resources, water quality, and aquatic life, as well as inadequate consideration of climate change, glaciers, and glacial lake outburst flood (GLOFs) events. Another contentious point was the minimum flow specifications for the project. While the Water Agency is the agency actually in charge of granting water rights and determining the flows - topics governed by the Water Code - impacts of the project's construction and operation, including minimum water flows, need to be evaluated under the EIA process. However, the Water Agency and COREMA were undergoing separate reviews at the same time. Fortunately, for the applicant, both agencies finalised their favourable approval at the same time. Otherwise, the EIA and water allocation processes could have conflicted with each other.

Notably, the EIA for HidroAysén exposed many deficiencies in the environmental review process at a time when Chile was in the process of joining the OECD. Following OECD recommendations, a reform process began in 2008 and concluded in January 2010. Since the ElA review for HidroAysén was underway, however, the ElA reform did no apply to the HidroAysén project. In any event, the amendment seeks to cure deficiencies noted in HidroAysén's EIA process, such as limited public participation, segmentation and institutional weaknesses.

The 2010 amendment created the Ministry of the Environment (to replace CONAMA, the National Commission on the Environment), the Environmental Evaluation Service (a specialised EIA agency), the Biodiversity and Protected Areas Service (to eventually take over CONAF's duties) and the Superintendence of the Environment (responsible for enforcement), in addition, other amendments to the EIA, including:

- Criteria for Approval/Rejection of EIA: amends the provision governing the criteria for approval/rejection of the EIA with respect to protected areas, clarifying that the EIA must consider impacts on 'resources and protected areas, priority sites for conservation, protected wetlands and glaciers, as well as the environmental value of the territory to be altered'.

- Segmentation: prohibits the segmentation of projects.

- Initial Review of the EIA: the EIA review begins with a 'rigorous' evaluation of the type of project and the process to be followed in order to avoid administrative errors. If the EIA lacks 'relevant or essential' information needed for its evaluation - that cannot be added or clarified - the environmental authority will make such pronouncement within 40 days from the original filing.

- Supplemental Information (Addenda): Within the 120 days of the review period, the environmental authority can requests additional or supplemental information and the review period will be suspended automatically (previously, it could be suspended by agreement). The proponent can request no more that two extensions of time in order to provide the necessary information.

- Public Participation in Addenda Process: The amendment requires public participation if an addenda to the EIA reveals significant environmental impacts. The proponent needs to publish the new information and the public will have 30 days to submit comments. Comments are open to any person (previously only recognized organizations and persons directly affected were allowed to submit comments).

- Compatibility of the Project with Regional and Local Land Use Plans: requires a report by regional and local governments (and the Maritime Authority, if applicable) stating whether the project is compatible with regional and local land use plans. The proponent needs to explain in the EIA how the project relates to such plans. 
In sum, the 2010 amendment recognised the lack of clarity in the EIA review, in particular difficulties presented by fragmented environmental responsibilities and the lack of a clear definition concerning their roles and coordination among them in the process, as well as limited public participation. Furthermore, the amendment acknowledged the frailty of local environmental authorities and the need to align the EIA process with environmental planning. The lack of coordination with the water law regime, however, remains the same, as discussed below.

\section{HidroAysén's water law conflicts}

Water rights for HidroAysén have become the most controversial aspect of the project. The main issues in this regard are not just the concentration of water rights in the region by the project developer but the request for additional rights. Other water users and environmental groups unsuccessfully sued under anti-trust laws (discussed in the section below) and have tried, unsuccessfully thus far, to halt the granting of such rights, which are essential for the project as approved in the EIA review.

A short background on Chilean water law is necessary to comprehend HidroAysén's water law conflicts. Chile's water law is based on the 1981 Water Code, amended in 2005, which declares that water is public property, but the state can grant private rights of use. ${ }^{44}$ Pursuant to the Code, water rights are in rem rights over water bodies, hence property rights of water use are completely separate from land ownership ${ }^{45}$ and entail the means to exercise such rights. ${ }^{46}$ They are subject to the general system of real estate title registration and can be freely bought, sold, mortgaged, and transferred like other forms of real property. Once granted, water rights are fully protected as private property rights under the Chilean Constitution and are governed by private or civil law rather than public or administrative law.

The Code distinguishes between consumptive and non-consumptive water rights. Consumptive water rights allow total consumption of the water right allocated. ${ }^{47}$ Non-consumptive rights allow water use, without consumption, with the obligation to return it to the water body, as stated in the act establishing the right. ${ }^{48}$ The Code also distinguishes between permanent, intermittent and continuous uses. Permanent uses allow total use of the water right allocated, unless there is not sufficient water in the water body at a certain time. ${ }^{49}$ Intermittent uses allow use of the water right when actual flows exceed those for permanent uses; $;^{50}$ uninterrupted uses allow water use 24-hours a day. ${ }^{51}$

The Chilean Water Agency evaluates requests for new rights, basically considering whether water is available, the requested water right is physically possible, it does not interfere with the rights of third parties and it is legally permissible. ${ }^{52}$ Applicants for new rights do not have to specify or justify their intended use to the agency. If there is not enough water to satisfy simultaneous applications, the agency must hold a public auction and sell the new rights to the highest bidder. ${ }^{53}$ Pursuant to the 2005 Amendment to the Water Code, rights-holders may request a change in location of the water right within the same water body, which will be granted if there is sufficient water, the rights of third parties are not affected and it is legally permissible. ${ }^{54}$ In order to implement the Code, the Water Agency issued a Manual of Standards and Procedures for the Administration of Water Resources, revised in 2008, and, in July 2010, issued Resolution No. 1800 , adopting criteria for granting water rights.

\footnotetext{
${ }^{44}$ Chile's Water Code, above $\mathrm{n} 7$, art 5.

45 Ibid art 6.

${ }^{46}$ Ibid art 8.

${ }^{47}$ Ibid art 13.

48 Ibid art 14.

${ }^{49}$ Ibid arts $16-17$

${ }^{50} \mathrm{lbid}$ art 18.

51 Ibid art 19

${ }^{52}$ Ibid art 22.

53 Ibid arts 141-150.

${ }^{54}$ Ibid art 163.
} 
In 1990, HidroAysén's patent company Endesa obtained non-consumptive, permanent, and uninterrupted water rights in the Baker and Pascua Rivers for the purpose of hydropower generation. In the Baker River, Endesa gained two rights, one for 1035 cubic meters per second $\left(\mathrm{m}^{3} / \mathrm{s}\right)$ and the other for $677 \mathrm{~m}^{3} / \mathrm{s} .{ }^{55}$ In the Pascua River, Endesa was granted two rights, both for 650 $\mathrm{m}^{3} / \mathrm{s}^{56}$ These rights were later transferred to HidroAysén, but with limitations. Two important points need to be made with respect to the transfer of water rights from Endesa to HidroAysén. First, in 2006, Endesa transferred legal title of the 1990 water rights to HidroAysén, ${ }^{57}$ but reserved all other legal rights over such rights, such as the right of usufruct. ${ }^{58}$ Second, to carry out the project, HidroAysén has leased the usufruct of the water rights from Endesa. ${ }^{59}$

The HidroAysén project needs more water, however. For Baker 1, in addition to the existing 677 $\mathrm{m}^{3} / \mathrm{s}$ flow, $250 \mathrm{~m}^{3} / \mathrm{s}$ for a total flow of $927 \mathrm{~m}^{3} / \mathrm{s}$; for Baker 2, in addition to the $1035 \mathrm{~m}^{3} / \mathrm{s}$ flow, $240 \mathrm{~m}^{3} / \mathrm{s}$ for a total flow of $1275 \mathrm{~m}^{3} / \mathrm{s}$; and for the Pascua dams, the existing $650 \mathrm{~m}^{3} / \mathrm{s}$ flows plus two more for $330 \mathrm{~m}^{3} / \mathrm{s}$ and one for $240 \mathrm{~m}^{3} / \mathrm{s} .{ }^{60}$ Consequently, in August of 2007, HidroAysén filed five applications seeking rights for these additional flows.

In October 2008, the regional director of the Water Agency denied HidroAysén's 2007 applications. The agency's denial concluded that the pre-existing (1990) rights were incompatible with the establishment of the requested rights. ${ }^{61}$ As expected, HidroAysén requested the General Director of the Water Agency in Santiago to reconsider the denials of the 2007 applications by the regional office, a recourse authorised by the Water Code. ${ }^{62}$ In July 2010, while the recourse was being considered, the agency issued Resolution No 1800, a resolution of general applicability seeking to clarify conflicting situations such as those at stake in HidroAysén's requests for additional rights. Resolution No. 1800 has been challenged in court by opponents of the project. ${ }^{63}$ On 13 May 2011 - the same day that the ElA for HidroAysén was approved - the Water Agency issued Resolution 14 granting the additional water rights for the project. But the additional water rights have not yet been secured. In August 2011, the Office of the Ombudsman intervened objecting to deficiencies in the approval and the case is likely to head its way to the Court of Appeals in Santiago. ${ }^{64}$

\section{HidroAysén's binational and anti-trust conflicts}

Opponents of the HidroAysén project have also filed petitions under arts 14 and 15 of the Canada-Chile Agreement for Environmental Cooperation Treaty, before the Secretariat of the Commission for Environmental Cooperation Canada-Chile, seeking an inquiry on Chile's compliance with bilateral environmental agreements regarding shared watersheds. ${ }^{65}$ The submissions claim that the Government of Chile has violated the Argentina-Chile Treaty for Environmental

\footnotetext{
${ }^{55}$ Dirección General de Aguas (República de Chile) Resolución No 52 de 1990; Dirección General de Aguas (República de Chile) Resolución No 164 de 1990.

${ }^{56}$ Dirección General de Aguas (República de Chile) Resolución No 39 de 1990; Dirección General de Aguas (República de Chile Resolución) No 159 de 1990.

${ }^{57}$ As per public deed dated October 10, 2006.

${ }^{58}$ Dirección General de Aguas (República de Chile) Resolución No 606 de 1990, 2 \& 4.

${ }^{59}$ As per public deed dated 3 December 2006 (which establishes a rent equivalent to 12.3 per cent of electricity generated with such rights for 30 years.

${ }^{60}$ HidroAysén's EIA, above n 36, 19-25.

${ }^{61}$ The Water Agency noted that (1) the requested right will interfere with the rights of third parties, which is prohibited by the Code (Article 22), because Endesa preserved the right of usufruct over the 1990 rights; thus, the establishment of the requested rights would affect Endesa's rights; and (2) the intake and return points for the additional water rights would be in different locations from those established in the 1990 rights.

${ }^{62}$ Chile's Water Code, above n 7, art 136.

${ }^{63}$ Environmental plaintiffs contend that the resolution is unlawful because it goes beyond implementation of the Water Code and intrudes into property law issues.

${ }^{64}$ Chile's Water Code, above n 7, art 137.

${ }^{65}$ Petitioners' documents are available at <http://www.patagoniasinrepresas.cl/final/acciones-legales. php>.
} 
Cooperation by failing to comply with the requirements set forth in the Treaty's Protocol for Shared Watersheds. ${ }^{66}$

Petitioners request that the Commission investigate whether the Government of Chile is complying with its environmental laws, in particular regarding compliance with the requirements set forth in the Argentina-Chile Treaty's Protocol for Shared Watersheds, which requires the preparation of watershed plans and consultations between the countries to protect the shared resources. While it is unclear whether this forum will resolve the dispute, petitioners have shown that the bilateral watershed regime is quite ineffective. ${ }^{67}$

Another interesting development in connection with water rights for the project concerns the anti-trust litigation against HidroAysén and Endesa for abuse of its dominant position in the Baker and Pascua Rivers brought under Chile's antitrust legislation - termed the Law for the Protection of the Free Market, herein Antitrust Law. ${ }^{68}$ The case relates back to 2007 when HidroAysén's parents companies, Endesa and Colbún, consulted with the Tribunal regarding their proposed joint venture for HidroAysén. In brief, the Tribunal gave them green light for the HidroAysén project, but imposed conditions including restrictions on holding water rights in certain water bodies (not the Baker and Pascua) and the structure of HidroAysén. Subsequently, water users mostly engaged in agriculture and tourism as well as several environmental groups opponents of HidroAysén brought an antitrust case in August 2009. ${ }^{69}$ The complaint alleged concentration of water rights in the Baker and Pascua Rivers in violation of the Antitrust Law. But the Tribunal never considered the merits of the case. In a decision in 2011, the lawsuit was dismissed on statute of limitations grounds, which was later upheld by the Chilean Supreme Court.

\section{Conclusion}

Conflicts surrounding the Pascua-Lama and HidroAysén projects in the Andes and Patagonia reveal the need to perfect the EIA review processes in place, specifically to implement mechanisms to ensure that water resources are adequately assessed, protected, and monitored. Clearly, environmentally sensitive water resources should be kept off-limits to hydro-energy and mining activities. Approaches that allows science-based delimitation of the sensitive water resources and of the measures needed to ensure their conservation - away from the environmental review and political processes - should be favoured. Weaknesses in public participation opportunities and meaningful ways to influence the EIA processes are also evident and need to be addressed, in particular to allow opportunities to comment as the evaluation proceeds through key stages, such as when substantial supplemental information is provided. In addition, there is an evident need for better coordination between the water managementallocation regimes and the environmental impact assessment of projects. This is particularly important where market-based water rights are recognized, as illustrated by water law conflicts in connection with the HidroAysén project in Chile.

On the positive side, the EIA processes for these projects seem to have effectively promoted inter-agency consultation, thus receiving a thorough technical review. Further, the ElA focus on mitigation and monitoring, resulting in concrete plans and measures, is noteworthy. But envi-

\footnotetext{
${ }^{66}$ See Agreement on environmental Cooperation (Chile-Canada) signed July 1997, <http://www.mma.gob.cl/chilecanada/1288/channel.html>; Canada-Chile Agreement on Environmental Cooperation (Chile-Canada), signed July 1997 <http://www.ec.gc.ca/ca\%2Dchil/>.

${ }^{67}$ The process has stalled pending responses by the Government of Chile.

${ }^{68}$ Chile's Antitrust Law (República de Chile) Decreto con Fuerza de Ley No 211 de 1973. The Antitrust Law created the Tribunal for the Free Market which is empowered to resolve controversies in matters covered under the Law, as follows: 'any situation, act or agreement that restricts or limits the free competition, or intended to produce such effects, will be sanctioned pursuant to Art 26 of the law, without prejudice to any injunction or preventive measures that may be necessary in each case to prevent such acts or agreements' (art 3). For its part, art 26 provides that the Tribunal can: modify acts or agreements that infringe on the fee competition; modify, or even terminate, the corporations involved in such actions; and, impose civil penalties.

${ }^{69}$ Antitrust litigation, No C 193-09. See Chile's Tribunal for the Free Market, at <http://www.tdlc.cl/>.
} 
ronmental authorities, supplemented with citizens' activism, must enforce the monitoring and mitigation measures during the life of the projects. Another positive aspect has been the availability of the EIA documents, including monitoring reports and enforcements, on the Internet, particularly in the Chilean system. Finally, the Argentine Glacier-Protection Law is a good example of legislative actions to protect glaciers, peri-glacial areas, and water resources at high altitude; although it remains to be seen whether it is properly implemented to safeguard these vital resources.

Keywords: Intergovernmental water agreements, water for hydro-power, environmental water, South American water law 